\title{
Close encounters of the Māori kind - Talking interaction in the films of Taika Waititi
}

Ocean Mercier

\section{Introduction}

Aspects of encounters between people on the marae provide useful metaphors for exploring conventions apparent in Māori films, which, by virtue of being made by Māori, tend to be situated within a framework that encapsulates marae tikanga and protocols. Two main types of encounter are found during official ceremonies on the marae: the pōwhiri, or first encounter ritual, which is enacted in the domain of the atua Tūmatauenga, and a less ritualised exchange that takes place inside the wharenui, within the domain of the atua Rongomatāne. It is argued here that the two short films of Taika Waititi each embody one of these two modes of interaction. In Two Cars, One Night, three children meet each other for the first time, and enact an hilarious and semi-ritualised form of encounter that parallels aspects of the pōwhiri. In Tama Tū, a group of young soldiers who are already acquainted enact an exchange of their own, one that follows the less formalised guidelines that govern interaction inside the wharenui. These modes of interaction, defining relationships between people from a Te Ao Māori perspective, also serve as an appropriate starting point for understanding and categorising films made on Aotearoa soil, on the tūrangawaewae of tangata whenua.

\section{Marae and Māori film - Rongomatāne (wharenui) and Tūmatauenga (paepae)}

"Māori film" is a problematic label on several counts. First, it is difficult to define what constitutes a Māori film: is the quantum of Māori in cast and/or crew, the presence of Māori in the most influential crew positions or the nature of the story the greatest determinant? Second, the term "Māori" is a post-colonial construct which frames the indigenous people of Aotearoa in relation to the coloniser. In Kaupapa Māori terms, "Māori" is an identifier that homogenises the individuality and uniqueness of tangata whenua as, first and foremost, descendants from waka, members of iwi and aligned to hapū. Additionally, the early "Māori" films were made in reaction to Pākehā ignorance and misconceptions about Māori as seen on the screen. It has been argued that Māori film be characterised as re-voicing Māori people (Mita 1992). While film as a medium does this 
for whoever controls the boom mic, so to speak, there is a danger of too narrowly defining "Māori film" as a reactionary medium, removing the mana marae of those voices.

Nonetheless, the existence of a genre known as Māori film, as opposed to Ngāti Porou, or Whānau-ā-Apanui film say, speaks to the collectivised nature of Māori film-making, that many times roots itself in the relationship between Pākehā and Māori. Merata Mita points out a fundamental difference in theme between Māori and Pākehā film, affirming that "...Māori films are driven by identity, resolution and survival" (Mita 1992:17). This dichotomisation between "Māori" and "New Zealand" films tends to force our cinematic work into one kete or the other. In seeking to resituate films within a Rongo(matāne) or Tū(matauenga) framework, I hope to present a less divisive categorisation.

And yet the term "Māori film" and the label "Māori filmmaker" survive. Taika Waititi recently confessed discomfort with the latter: "Let's just say I'm a filmmaker who is Maori and some of my films are going to have a lot of Maori content and some aren't. Why can't I just be a guy who writes stories and puts them in a film? Why can't I be a tall filmmaker? Or a black-haired filmmaker?" (White 2005:76). Asked recently what constitutes a Māori film, Barry Barclay replied in a similarly disenchanted note "Māori have always just said we make it as Māori and if you are in the Māori world act within the Māori world." (Reid 2001:B6) We can say that a principal feature of "Māori film" concerns the central characters and goals. In contrast to the classical Hollywood narrative, and more in line with Asian cinema, Māori films (eg Ngāti, Mauri) have tended to eschew the individual's journey, and preferred to follow a communal narrative to a form of resolution that is satisfying on the hapū or whānau level. This typifies the tikanga during a hui at a marae, in which all are encouraged to contribute to the broader development of the hui's narrative.

Barclay, reflecting on his direction of documentaries for the Tangata Whenua series and The Neglected Miracle, refers to this as "a marae approach" (Barclay 1992:119). He sought to have all opinions heard, and for all voices to speak for themselves. This is a principle that presides over hui in the wharenui on the marae, said to be under the domain of Rongomatāne.

On a marae, there is opportunity for all to speak, be it on the paepae, through song in the dining room, or late at night in the whare nui. Mana is recognised, of course, but over the days of a hui, the little person, the 'nobody', is given room too. Those who are over-bold are pulled down a touch, and those who are timid are supported. It 
matters little whether you happen to be a city lawyer or a breaker of horses. All have a voice. (Barclay 1992:119)

Those who have opted to participate are expected to contribute, no matter how young. This idea, being deeply rooted within Māori philosophy in general, not just on the marae, naturally spills into the medium of Māori film, and can be seen in the films of Barclay, Taika Waititi, Merata Mita and Lee Tamahori, four of the most prominent Māori film directors. By contrast with the orderly karanga and whaikōrero during the pōwhiri, the dialogue within the wharenui is more exploratory, experimental even. It seeks to advance the collective knowledge and wellbeing of the community involved, by valuing the opinion of each individual in the community.

Within Kaupapa Māori Research the marae has been mined for Māori models of health, politics and education, to name a few disciplines. One example particularly relevant to this discussion is the 2-house ( $\mathrm{Ngā}$ Whare e Rua) model of post-colonial partnership between Māori and Pākehā (Jackson and Poananga 2001). This describes the brokering of relationships between the Māori house (wharenui) and the Crown house (government). Also pertinent here is Mason Durie's theorising of a Māori psychology informed by marae practice (Durie 1998). The approach in this paper is to argue for a broader interpretation of the category generally known as "Māori film" under the mantle of two new interpretive frameworks that have wider application: the Rongomatāne (or wharenui) category and the Tūmatauenga (or paepae) category. The Rongo framework, reminding us of the domain within the wharenui or meeting house on the marae, speaks to films that describe insider stories; and included within this grouping are the films made by Māori, about Māori, for Māori. The Tū (paepae) framework makes reference to the situation of Tūmatauenga on the marae-ātea, who is awakened when a pōwhiri, or ritual encounter is about to take place on the marae. This grouping describes encounter situations in which a negotiation of a new relationship is a central theme in the film, for instance those between Māori and Pākehā, or different iwi, or any other groups. By following this convention, the nature of interaction is emphasised rather than the ethnic or racial nature of character, cast or crew.

The inferred egality of encounters on the marae in the domain of Rongomatāne then is similar to the typical presentation of characters in the canon of Māori film. While some have little to say, there is a sense in which Māori characters are not put on the screen for tokenistic purposes. This is often seen in Hollywood style films, to the extreme that some characters are on screen merely to be killed off. In Māori film of the here-defined Rongo 
category, each has a character and significance to the wider narrative, examples in point being Ngāti, Mauri and Tūrangawaewae. Equal time and prominence is similarly given to all characters in both of Waititi's short films, which are considered in depth here.

The two short films of Taika Waititi, Two Cars, One Night and Tama Tū, illustrate the features of each category. Tama Tū observes the non-verbal exchanges between members of 28 Battalion, holed up in a ruined building in Italy, WWII. In detailing established relationships between the soldiers, this film represents characteristics of the Rongo category. In Two Cars, One Night, a primary encounter situation is negotiated between prepubescent youngsters. The progression of their relationship throughout the film is reminiscent of encounter conventions seen on the marae-ātea during a pōwhiri, enabling this film to be analysed within a Tū framework. Although Waititi's characters all happen to be Māori, being Māori is not the criteria for distinguishing Tū and Rongo films. Waititi's films are set on canvasses primered with the coloniser's landscape, historical backdrops that Māori are all too familiar with, and yet the voice given to his characters is distinctly Māori. This paper discusses aspects of each of the two short films, then concludes by discussing other Māori and Aotearoa New Zealand films within the context of these new categorisations.

\section{A Primary Encounter negotiated - Tūmatauenga (paepae) - Two Cars, One Night}

Individuals or groups mark the occasion of a first meeting and set each other at ease by performing some mutually acceptable ritual. The exact rituals differ depending on the cultural background, age, gender and number of the people involved, with personality playing a role in the choice and interpretation of the appropriate rituals. In Western cultures, for example, a first meeting may be marked with a hand shake. Amongst Māori, the hongi and the kihi are accepted and popular, the former generally favoured between kaumatua and men, the latter more likely to be used between younger people and women. For bringing together large groups of people, the pōwhiri carried out on the marae is an elaborate ritual form of encounter designed to remove barriers and build relationships between people on a large scale. When an ope arrives on a marae, generally by invitation, they are identified as the manuhiri. As guests they are obliged to follow the meeting rituals of the haukainga (lit. home breaths), who are kaitiaki of the marae. During the powhiri, the marae-àtea, or space in front of the wharenui, becomes tapu, or in a state of potential danger. Tūmatauenga, the god of war and humankind, is said to be awakened at this time, heightening the importance of the meeting groups carrying out the proper rituals correctly from their respective space or paepae (seating area on either 
side of the marae-ātea). This state is maintained until the others' intentions are established and accepted, and the parties move to cement their new relationship as whanaunga.

The short film Two Cars, One Night examines a first meeting, a Tūmatauenga situation, between three children of Te Whānau-ā-Apanui on the East Cape. While their encounter does not take place on a marae, parallels can be drawn between the rituals of encounter encompassed in the pōwhiri, and those demonstrated between the characters of this film. There is a universality about the encounter rituals displayed amongst Māori, whether they be between groups or individuals, on the marae or at the pub. This is not surprising, as in any first encounter, there is whakapapa to be established, and physical, spiritual and emotional barriers to be overcome before deeper relationships may form. The five aspects of the marae encounter that will be considered here are space, time, karanga, whaikōrero and koha.

A scene near the film's beginning shows a car pulling in to the Te Kaha pub carpark, and parking a distinct and deliberate distance from one other car there. This physical distance, emphasised in the wide shot and the choice of black and white cinematography, represents the physical distance between strangers and can be seen as having the same purpose as the space on the marae-ātea between manuhiri and haukainga. Mason Durie (1999) recognises the importance of maintaining an appropriate physical distance between strangers and calls this the domain of space. Durie discusses the importance of conceptualising a Māori whakaaro centred around marae rituals, terming the theory, which touches on nine aspects related to marae protocols, a "marae psychology". Aspects of his theory can be usefully applied as an interpretive framework within which to re-examine relationships within Māori films. The two boys waiting in the first car, Romeo and Ed (brothers of 9 and about 7 years respectively), are on uncomfortable ground, their parents having left them to wait while they drink at the pub. However, Romeo and Ed being in the territory of the car-park before Polly (12 years), naturally claim this space as their own, their temporary stomping ground. This is also evidenced in Romeo's use of the space, particularly later in the film when he crosses it to talk to Polly, his comfort with it at least signifying a belief in his "ownership" of it. This invites us to consider Polly as playing the role of the manuhiri and Romeo and Ed the role of haukainga. It is worth noting also, that it was the parents parking the cars who defined the space, this marae-ātea, by parking their cars in their particular juxtaposition. Through inexperience and youth, the three children are unable to move beyond the spatial confines of the two cars. This serves to suggest the influence of ngā tūpuna on our practices related to the marae. These tikanga are predefined, and the rituals are similar, but our interpretation of them as individuals, and groups of individuals, is in a sense free. 
Durie invites us to consider that Māori time, or the marae domain of time, rather than a frank disregard for time, adheres to a more fundamental time sequence (1999). Time is different in Māori thinking, reflecting the need for a closer analysis of the use and meaning of time in Māori film. Time is manipulated in two main ways during Two Cars, One Night. Black and white cinematography superficially conveys a bygone era, as does the appearance of 1950 s and 1960s model vehicles. However, the reference to Johnny Depp, smoking outside the pub and the verbal jibes, "Egg" and "Having a good jack?" for instance, centres it in present days. Removing colour entices us to reflect on the basics of light and shade - in a black and white world, the world of the central child characters, life is simpler, less complicated by the issues of adult life. However, the director challenges this notion almost as immediately as he suggests it. Life as a child is often about reaching for the complexities of adulthood, he reveals: "I thought of ... how children perceive the world and how they take on some adult themes sometimes and the way they translate that in their conversations with each other" (Cardy 2004). The complexity of children playing predefined adult roles is poignantly backlit by a situation in which they have been left in positions of responsibility, sometimes self-appointed ("I'm gonna drive us home...cos our olds will be wasted."), while their parents indulge in so-called adult activities. In Polly and Romeo's interactions, they have not yet built up the boundaries adults must overcome in encountering each other.

Shots in the film that deal with events external to the centre stage, the two cars, are fast paced. For instance, the over-cranked opening scene of speeding cloud and incoming traffic, and the flaming cigarette ends of smokers, contrast with a carefully measured pacing of events and dialogue on the main stage. Although this mainly serves to accentuate the length of time that the children have been left outside while the parents drink in the hotel pub, it also reminds us that on the marae, time is seen as an elastic, rather than linear, concept (Durie 1999). The slow pace of the film at the end, showing Romeo and Polly's final gaze at each other, serves to further highlight the denouement moment of the film.

Initial interest in the boys and the expectation to engage is first shown by Polly, whose furtive glances over at the occupants of the boys' car invite interaction. This reminds us that on the marae, the first call to engage, whether through the welcome of the haukainga or reply of the manuhiri, is always made between women representatives, the kaikaranga. In this case, Polly is the more mature of the trio, and interactions may have begun more civilly if played according to her rules. However, the rules of engagement are about to be set by Romeo. 
When Ed first remarks "that girl's looking at us", Romeo challenges her gaze, by pulling a face. He follows his taunts "Hey, ugly, uuugly", with the upraised finger once he has regained her attention. Polly replies in kind with a counter-challenge of her own, a mixture of verbal "hey dick, I mean hey boy" and gestural (two middle fingers upraised) communication. While no common interest is yet apparent, these exchanges are necessary enactments of authority. Significantly, their exchange occurs from the safe space of their cars, and with a safe distance between them. Jibes and digs thrown back and forth remind us of the whaikōrero, performed between speakers on opposite sides of the marae-ātea. The nature of orations performed across the space at a powhiri can be contentious indeed, and are undertaken under the restrictions of tapu and in the domain of Tūmatauenga. These speeches probe towards common understanding, however, so it is less the nature of individual comments than engagement in the exchange that matters for forging a relationship. When Romeo closes the space-gap, his conversation likewise seeks to bridge the ground between them. While posturing is still a feature of his side of the exchange in particular ("bet you don't know any boy gays like me"), he acknowledges her (seniority "12 [years]? Jees neat alright girl.") and gives due attention to her words, seeking to involve Ed in the conversation as well. A segue to a later scene shows Romeo in the car, then sitting shoulder to shoulder with Polly. Having effected the appropriate rituals, they are now "on the same wavelength", and can share a mutual wharenui-like space as one people.

Near the end of the film, Polly gives a "diamond" ring to Romeo with the express caveat that "it doesn't mean we're married". The gift, symbolically given by the manuhiri in an enactment of koha, plays with Western notions of ring-giving in consummation of advanced relationships, which is almost exclusively initiated by the male of the heterosexual relationship. In Māori society, gender roles may traditionally (and even now) have been rigidly demarcated, however the difference between male and female gendered behaviour is much less clearly defined. The koha given at the pōwhiri, while nowadays typically monetary, should be something that is precious, and in times past included taonga that were unique to the area the manuhiri came from. When Romeo claims that he wouldn't sell the ring, he reveals it symbolises far more to him than the money it may be worth (though they both know it is merely plastic), reminding us as Māori of those things, such as aroha, whānau and whenua, that should not be commodified.

Other ritualised encounters feature in the movie. Romeo and the man adorned with tā moko raise eyebrows at each other. This is seen as a typically Māori greeting, even featuring 
as the punch-line in the racist joke "How do Māori answer the telephone?" The old man greets the boys with "Tēna kōrua", and they respond to him with raised eyebrows.

The central situation of the children being left in a car park while their parents drink in the pub is symptomatic, in the same way that Once Were Warriors (or Reina Webster's The Little Things) was, of the neglect and problems that arise through a shift in values, typically depicted through alcohol dependence. In Apirana Taylor's poem Sad Joke on a Marae, the narrator, Tu, recites his whakapapa: "Ngati DB is my tribe, the pub is my marae, my fist is my taiaha, jail is my home" (Taylor 1979:15). Using Māori norms of identification with a tribe and a marae, Tu introduces himself to the carved ancestors in the wharenui. Tu's separation from a traditional Māori worldview is painfully self-evident, however. His identification of the pub as his marae, in a sort of confession to the "tekoteko and the ghosts" (Taylor 1979:15), is an admission of his removal from the world of his ancestors. Perhaps not implied in the poem or this film, but certainly understood, is that feeling closer to the pub than to the marae is one of the flow-on impacts of colonisation and subsequent urbanisation of Māori. Waititi's suggestion, however, is that alcohol dependence in some need not commit their children to the same path. Two Cars, One Night, centres on a positive interaction between the youngsters, providing a hopeful scenario of a people overcoming the effects of colonisation on their society. Also implied is a global unification of the struggles of young indigenous peoples against colonial powers. Ed is reading The Fetterman Massacre by Dee Brown, an account of the 1866 battle of Little Bighorn told principally through the surviving writings of white American militia men. Ed's re-centralisation of the Lakota leader known as "Crazy Horse" - though scarcely mentioned in the book - as being its subject, shows a clear identification with the young native American warrior. Ed's struggle, as a potential leader, is one of taking on Western tools of education to teach himself about the coloniser. Both of Waititi's films depict the continued survival of Ngāi Māori within a colonial state. This survival is managed through humour and the solidarity gained through meeting and consolidating with each other. While many Aotearoa/New Zealand films have concerned themselves with biculturalism and Māori-Pākehā relationships, Two Cars, One Night and Tama Tū centre on a Māori interaction placed within a society reflecting a colonial past and heritage. The prevalent New Zealand film ideology is still one of decentralising, descreening, or assimilating "the other", that is, Māori. Waititi's films reverse this, by centralising, screening and inhabiting Te Ao Māori. In both short films, his Pākehā are in fact not "the other" but become "the absent". 


\section{“All Have a Voice”, Rongomatāne (wharenui) - Tama Tū}

It is ironic to assert that "all have a voice" (Barclay 1992:119) in Taika Waititi's 2004 short film Tama Tü, in which the only voice heard occurs just before the final credits roll. And yet this film, in which equal importance is given to every character, and insider camaraderie and reinforcement of collective identity is thematic, exemplifies the Rongomatāne (wharenui) film.

The film's title carries a double meaning. The press kit translates Tama Tū as "Sons of Tū(matauenga)", meaning soldiers for the atua of war and man. Yet viewers also familiar with the whakataukī "Tama Tū, tama ora, tama noho, tama mate" will note the ironic play on the title. The proverb is literally translated as "He who stands up, lives; he who lies around, suffers for it." Tama Tū (he who stands) satisfies some of the conventions of the war genre. It is certainly not, however, an action film, and for the most part chronicles a group of soldiers sitting around. The boredom of this lull is filled by the roguish behaviour of six members of the 28 Māori Battalion. The interaction keeps these soldiers alert and poised for action, waiting for nightfall whilst hidden in a ruined building in World War II Italy.

The brooding danger of the unseen enemy muzzles them into a non-verbal form of communication with each other. While soldiers' voices were often muted by the war surrounding them, members of the Māori battalion were willing to fight this war in order to gain recognition for the one fought at home. Theirs was not simply a fight for the overthrow of a distant dictator, but a fight for equality (Keenan 2005) and recognition of Article 3 of the Treaty of Waitangi, that Māori be treated as equal citizens under Crown rule, and sovereign over their own whenua. They bear the words "New Zealand" on their epaulettes, branded by a society that had given them but limited power to speak, yet sought to own their courage and willingness to sacrifice. In this, a film by Māori, about Māori, it is significant that a soldier is never seen to show patriotism or loyalty to any flag or nation. The only loyalties here are those to each other. This is a whānau of a different character, an iwi-based consolidation of kaha and kotahitanga.

Significantly, none of the soldiers are named in the movie or in its credits (though the press kit assigns names and profiles to each character). Their collective identity is more important, both from a Māori and a military perspective. The suppression of the individual and objectification of the soldier as a dispensable unit is evident. Not only are the soldiers silenced, but their individual stamps of identity are only revealed through their personality traits. 
Just as Waititi's earlier work featured pre-pubescent children, so the characters in Tama $T \bar{u}$ are young, with most of the soldiers depicted probably in their early 20 s. This is reflected in the juvenile and sometimes puerile prankery they engage each other in, for instance the wetting of a sleeping lad's groin area, and the "pull my finger" flatulence gag. While audiences respond with hilarity, the comedic nature of the soldiers' interaction only serves to heighten our sense of their situation. As in Two Cars, humour holds its characters and backdrop in stark relief. Audiences observe knowing the extent to which men were lost in World War II, and the likely fate of these six.

Tama Tū speaks in insider language, yet with a universality and deft hand of observation that requires no translation. The viewer, Māori or non-Māori, becomes an insider by virtue of being treated as an insider, and this no-holds-barred speak is conducted as though these audiences find themselves within the marae domain of Rongo. As mentioned, equal importance is given to all actors within this domain. We recognise the principle of having equal communication rights, applied during discourse within the wharenui, at work in the exchanges in Tama Tü. At the beginning, the wordless exchange of bullets and cartridges through elaborate hand gestures and hand signals are classic motifs of small military units. The teamwork of a well-oiled unit is evident here, when the core business of the unit is to ensure all are adequately armed to subdue the enemy. The non-verbal "eyebrows up" greeting also evident in Two Cars, One Night, while used in a humourous way here, also serves to acknowledge other members of the unit and provide moral support and solidarity. Even the use of Te Reo Māori in the karakia at the end, in its juxtaposition with the imagery of a circle of six heads bowed over in collective recitation, clearly conveys the strength, protection and even eternality of the bond these soldiers have with each other.

The key event book-ending the movement in the film is the appearance of a crow. Māori associate the piwaiwaka with death, and its song recalls Māui's failed attempt to secure immortality for humankind. When the crow flies into the same space as the soldiers, their mirth quickly subsides, and all understand the tohu that death is close by. There is practical significance behind its appearance too - is the crow there to give their position away, is it an agent for another power?

Following the appearance of the tohu, a karakia, the only spoken dialogue in the film, emphasises the special group dynamic and the power derived from the spoken word. Even to a non-Māori speaking audience these words are imbued with significance through their quiet resonance in the open air, through the previous absence of audible voices, through 
the use of Te Reo Māori and through the collective utterance, at the conclusion, of their affirmation; "Haumi e, Hui e, Tāiki e". It is significant that the end of this karakia is supported by a waiata, which in both the Tūmatauenga and Rongo domains on the marae are used to whakanoa the person speaking with the atua, whether through karakia or giving a whaikōrero. The song Au, E Ihu (Here Am I, Lord), performed by the 28 Māori Battalion and recorded in 1943, resonates with the modern day affirmation of the voices of actor Cliff Curtis, and musicians Riki Gooch and Rio Hemopo.

The tin soldier, standing on a mound of rubble, represents the 'Tama Tū' who left him there. He stands because his kaitiaki, represented by the carved manaia, stands behind him. He is at once fully soldier, and fully Māori, representing the traditions and ways of the ancestors in culture and in war. These will last beyond the waste of the city, beyond even his own demise. A significant feature of the placement of the manaia next to the tin soldier is the communal effort represented. While Boy was earlier seen to enact a mock dust attack against the figure, it was Paki who carved the manaia and Boy who left them together as a token of the protection they seek for themselves. That these soldiers sought and found solidarity through interaction with each other as whanaunga, as a special unit reliant upon the other and stronger together than apart, exemplifies the wairua of Rongo. May they rest in peace and remain ever with us.

\section{The Wider Picture - Rongo and Tū films in Aotearoa}

If Māori film is to be defined as being made "by Māori about Māori for Māori” (Mita 1992:16), where does that leave the significant body of film that includes the work of Māori, and draws upon Māori resources but is not directed or produced by Māori? The marae paradigm, in describing two types of encounter between people, re-centres our interpretation of films involving Māori, from within Te Ao Māori. It seeks to rethink the defining question of "how much Māori involvement was there?" This Māori worldview distinguishes between types of encounter, and defines and reaffirms who we are as individuals within communities, possessed of a whakapapa and sharing Aotearoa, Māori and Pākehā together. As such it is able to cast a wider net across all cinema produced on Aotearoa soil.

Tama Tū and Two Cars, One Night conveniently illustrate the Rongo and Tū situational contrasts. Two Cars even displays significant parallels to the pōwhiri ritual of encounter, by highlighting the role of space, time and reciprocation in a newly brokered relationship. The name of the movie is a reference to the dimensions of space and time and the synchronicity 
of a friendship born when occupants of two cars interact during the course of one night. An interesting aspect of the Tū category is that, reflecting pōwhiri tikanga, only certain voices are chosen to be heard, through the karanga and the whaikōrero, to represent the group. In a Tū film, some characters' voices may be subsumed into those chosen to represent them. Ed makes it clear he would prefer to read, though he interjects in the discussion between Romeo and Polly when correction and affirmation are required.

River Queen and Utu are not generally thought of as Māori films, though they feature Māori prominently, and display intercultural conflicts that are resolved through the resolution of the relationship between key Māori and Pākehā protagonists. However, both of these films can be described as Tūmatauenga, or paepae films, focussing as they do on the negotiation of encounters between colonists and tangata whenua. The 2 -House model can be invoked for these films. They feature involvement from those in the wharenui, but the rules and mode of presentation are dictated by being in the "Master's house", the stories being told from Pākehā perspectives. Overall what is seen is an encounter situation on the "Master's" paepae. Whale Rider is also generally thought of as a Māori film. However it would fall outside Barclay and Mita's understanding of one. Directed by Niki Caro, a Pākehā woman, it was also adapted by her from the Witi Ihimaera novel to follow a more traditional Hollywood narrative (complete with unambiguous happy ending) and a Western political narrative (women's equal rights). In the 2-House model, we can think of Whale Rider as being made on the Master's estate, but as describing a Rongo situation, in which existing relationships are renegotiated, wharenui style. Classical Hollywood narrative tends to work in opposition to a Māori whakaaro of allowing dialogue to evolve and all to have a say. As a further example, the feature film Ngāti can be seen as displaying both Tū and Rongo characteristics. Its negotiation of new and existing relationships reaches across the paepae into the wharenui. The marae is also physically central to significant plot developments in Ngāti. My suggestion here is that all films in Aotearoa can be thought about in terms of a marae framework in concert with the 2-House model, as they have all been filmed within a society which, acknowledged or not, is underpinned by tangata whenua notions of tūtaki tangata (people meeting).

\section{Conclusions}

This paper has sought to provide an understanding of Māori films within a framework that emphasises the importance of marae custom and practice. Using theories from Kaupapa Māori ideology allows a more natural and appropriate interpretation of films made 
in Aotearoa with the involvement of Māori. Rather than being simply a "Māori film" or a "Pākehā film", within this interpretation Aotearoa films exemplify Rongomatāne (wharenui) or Tūmatauenga (marae-ātea) characteristics in either the Master's house or the Wharenui, from the 2-House model of Kaupapa Māori research. These categorisations centre the key types of interaction between characters, in much the same way that the genre labels of drama and comedy stimulate expectations of a certain mode of interaction and dialogue. In addition, they are seen as pertaining particularly to Māori films, and provide a specificity of information that eludes the classification of "Māori film". Furthermore, by viewing all films that involve Māori within this framework, the dichotomy of "Pākehā film" and "Māori film", and the subsequent divisions over ownership, are more appropriately dealt with.

\section{Acknowledgments}

I am very grateful to the two anonymous reviewers of an earlier draft of this paper, whose comments greatly improved both my thinking on this topic, and the paper that eventuated.

\section{Glossary}

Aroha

Atua

Hapū

Haukāinga

Hui

Iwi

Kaikaranga

Kaitiaki

Karakia

Karanga

Kaumatua

Kete

Koha

Manaia

Manuhiri

Marae

Marae-ātea

Paepae
Love

\section{Primal god}

Sub-tribe

Hosts, home people of the marae

Meeting

Tribe

Woman performing call of welcome

Guardian, spiritual overseer

Prayer, incantation

Call of welcome or response during pōwhiri

Elder person, one possessing wisdom

Basket, usually woven of flax

Gift

Carved figure representing spiritual guardianship

Visitors, guests

Meeting place, with central focus the meeting house

Space in front of meeting house

Threshold of the meeting house, a tapu place during pōwhir 
Pōwhiri

Rongo(matāne)

Tangata whenua

Taonga

Tapu

Tēnā kōrua

Tikanga

Tohu

Tū(matauenga)

Tūpuna

Tūrangawaewae

Waiata

Wairua

Waka

Whaikōrero

Whakaaro

Whakanoa

Whakapapa

Whakataukī

Whānau/Whanaunga

Wharenui

Whenua
Welcome ceremony for visitors to marae

The god of peace and cultivated foods

People of the land

Item of great value

Under ritual restriction, sacred

A formal greeting to two people

Customs, protocols

Omen, sign

The god of war and humankind

Ancestors

Place of origin, lit. standing place for feet

Song

Spirit

Ocean craft that brought Māori ancestors from Polynesia

Speech performed during the pōwhiri

Thought, idea, philosophy

Process of removing tapu, and making something noa

Genealogy

Proverb, ancient saying

Family/Family member or kin

Meeting house on marae

Land 


\section{References}

Barclay Barry 1992 Amongst Landscapes in Jonathan Dennis and Jan Bieringa (eds) Film in Aotearoa New Zealand Wellington Victoria University Press

Brown Dee 1972 The Fetterman Massacre London Barrie and Jenkins

Cardy Tom 2004 Spreading His Wings Dominion Post May 7

Durie Mason 1999 Marae and Implications for a Modern Māori Psychology Journal of the Polynesian Society 108 351-356

Jackson Moana and Poananga Atareta 2001 Nga Whare e Rua 2-House Mode/ Wellington Keenan Danny 2005 MAOR123 Lecture Module Wellington Te Kawa a Māui

Mita Merata 1992 The Soul and the Image in Jonathan Dennis and Jan Bieringa (eds) Film in Aotearoa New Zealand Wellington Victoria University Press

Reid Grahame 2001 Present tense, future perfect New Zealand Herald B6 10 December

Salmond Anne 1975 Hui Wellington A H \& A W Reed

Tama Tū Presskit 2005 Available internet http://www.tamatu.co.nz/ Accessed June 5th

Taylor Apirana 1979 Sad Joke on a Marae in Eyes of the Ruru Wellington Voice Press

Waititi Taika 2003 Two Cars, One Night Defender Films Ltd

Waititi Taika 2004 Tama Tū Defender Films Ltd

White Mike 2005 No End of Stories North and South 234:72-76 